\title{
The Effectiveness of Purslane Extract Provision on Liver of White Rats (Rattus norvegicus) with High Fat Diet
}

\author{
Yuli Susana $^{1}$, Lucia Tri Suwanti ${ }^{1 *}$, and Lianny Nangoi ${ }^{2}$ \\ ${ }^{I}$ Department of Veterinary Parasitology, Faculty of Veterinary Medicine, Universitas Airlangga, Surabaya, East Java, Indonesia \\ ${ }^{2}$ Department of Clinical Veterinary Medicine, Faculty of Veterinary Medicine, Universitas Airlangga, Surabaya, East Java, Indonesia \\ *Corresponding Author's Email: tswant@gmail.com; (DoRCiD: 0000-0002-3702-3148
}

\begin{abstract}
Most animal owners provide fatty food with high cholesterol level that exceeds the needs of their pets. The pattern of giving a high-fat diet causes interference with the cholesterol synthesis in the body. It can damage the liver by causing fatty degeneration, hepatic cirrhosis, and eventually necrosis of the liver. The purpose of the current study was to determine the effectiveness of Purslane extract (Portulaca oleracea L.) on the liver histopathological image of white rats (Rattus norvegicus) with a high-fat diet. The current study used an experimental method with a completely randomized design on 20 males white mouses (Rattus norvegicus) divided into five treatment groups. There were two control groups, the first group received standard feed (Pellet) and Carboxymethyl Cellulose Sodium $1 \%$, while the second was given standard feed and a high-fat diet. Three treatment groups which included P1, P2, P3 were given standard feed, a high-fat diet, and purslane extract solution with $54 \mathrm{mg} / \mathrm{day}, 108 \mathrm{mg} / \mathrm{day}$, and 216 $\mathrm{mg} /$ day, respectively. Research results from the mean rank of fatty degeneration which was measured using the Kruskal Wallis test presented significant differences, and the results from the mean of fatty degeneration using the Mann Whitney test did not indicate any significant difference. Liver cell necrosis from the two tests presented a significant difference. Purslane extract (Portulaca oleracea L.) was confirmed to be effective in reducing or decreasing hepatocyte cell damage after receiving a high-fat diet.
\end{abstract}

Keywords: Fatty degeneration, High-fat diet, Liver necrosis, Portulaca oleracea L., White rat liver

\section{INTRODUCTION}

Recently many animal owners, especially pet owners have been providing fatty food with high cholesterol levels that exceed the normal needs of the pet body (Lichtenstein et al., 2006). Cholesterol is a result of the body metabolism of edible fats (Ghadir et al., 2010). Increased exogenous fat, such as consumption of a high-fat diet, will increase the triglyceride content in the liver. In a study on mice, an increase in hepatic triglyceride content ultimately occurred within 10 days after receiving a high-fat diet (Den Boer et al., 2004). The pattern of giving a high-fat diet interference with the cholesterol synthesis of the body. It can damage the liver, which causes fatty degeneration, necrosis, and in a state of continuation, can cause liver cirrhosis and chronic liver disease since the cholesterol is synthesized, especially in the liver and intestinal wall (Murray et al., 2003).

High consumption of fat can produce free radicals or oxidants through chemical changes process which is called "oxidation" (Calleja et al., 1999). The main target of free radicals are proteins, unsaturated fatty acids, lipoproteins, and DNA. The earliest known and most widely studied mechanism of cell or tissue damage due to free radical attack is lipid peroxidation. Most lipid peroxidation occurs in cell membranes, especially in unsaturated fatty acids which are the important components that make up cell membranes. This lipid peroxidation will affect fluidity, structure, and function of cell membranes and affect individual metabolism, including lipid metabolism, and cause lesions in the liver tissue in the form of lipotoxicity (Chao et al., 2001; Koch et al., 2007).

One type of herb that has the potential to reduce cholesterol levels and contains enough antioxidants that can be used to improve damaged cell function is Purslane (Portulaca oleracea, Babazadeh et al., 2021). Purslane is one of the weeds that can be used as a source of natural antioxidants. It has high iron and omega-3 content (Balk et al., 2006; Cheng et al., 2021). Purslane contains the highest omega- 3 fatty acids among vegetables that have been studied previously. The Purslane omega- 3 fatty acids prevent the formation of free radicals by donating an electron to the lipid biomembrane, as a result, the stability and functional integrity of the cell membrane will be increased (Besong et al., 2011).

The utilization of purslane as a therapeutic agent for hypercholesterolemia has begun to spread. Thus, the current study aimed to determine the effectiveness of Purslane extract provision (Portulaca oleracea L.) on liver histopathological images in white rats (Rattus norvegicus) with a high-fat diet. 


\section{MATERIALS AND METHODS}

\section{Ethical approval}

All experimental protocols and procedures were approved by the Institutional Animal Care of Indonesia.

\section{Experimental design}

This study had an experimental research design with a completely randomized design. The variables included independent, dependent, and control variables. The independent variable was the dose of Purslane leaf extract (Portulaca oleracea L.), the dependent variable was the microscopic histopathology of the white rat liver and the control variables were experimental animals and their gender, body weight, food, age, and environment

\section{Materials}

Materials used in the current research included $10 \mathrm{~kg}$ fresh Purslane leaf extract (Portulaca oleracea $\mathrm{L}$.) which had been cut into small pieces, then aerated until it became dry, then it was made into simplistic powder. Simplisia was immersed in 96\% ethanol for three days and then given a multilevel dose (Besong et al., 2011). Another material that had been used as a high-fat diet was lard. The common dose of lard for humans is $150 \mathrm{mg} / \mathrm{day}$, then the dose was converted for white rats and it was equaled to $0.018 \times 150$ grams $=2.7 \mathrm{grams} / 200$ grams BW/day. Thus, the provision of lard in white rats was 3 grams/200 grams BW/day (Ariantari et al., 2010). A high-fat diet suspension was made by mixing 300 grams $(399.9 \mathrm{~mL})$ of lard and 200 grams $(230 \mathrm{~mL})$ of duck egg yolk into $100 \mathrm{~mL}$ water and $1 \%$ Carboxymethyl Cellulose Sodium (CMC Na 1\%) $1 \mathrm{ml}$.

\section{Sampling}

The experiment was performed on the livers obtained from 20 male white Wistar strain rats aged 8-12 weeks with an average body weight of 150-200 grams. Standard feed and drinking water were given ad libitum to all-white rats (Rattus norvegicus). A total number of 20 male white rats, were randomized completely based on 5 treatments (with 4 rats in each group) and each treatment had 4 replications (Kusriningrum, 2012). Rats were placed in individual cages by randomization. Prior to the treatment, the rat was adapted for seven days in the Experiment Animal Cage of the Faculty of Veterinary Medicine, Universities Airlangga, Surabaya. This study lasted one year. Each treatment group consisted of four rats. The negative control group (K-) received standard feed (Pellet) for 56 days and $1 \mathrm{~mL}$ of Carboxymethyl Cellulose Sodium $1 \%$ (CMC Na 1\%) from the 29th day to the 56th day. The positive control group (K+) received standard feed and a high-fat diet for 56 days. The P1, P2, P3 treatment groups were given standard feed and a high-fat diet for 56 days, and Purslane extract solution with $54 \mathrm{mg} / \mathrm{day}, 108 \mathrm{mg} / \mathrm{day}$, and $216 \mathrm{mg} / \mathrm{day}$ doses which were added from days 29 to 56 , respectively.

\section{Histopathology of rat liver}

At the end of the study, the rats were euthanized and their livers were removed. The rats had been euthanized under direct observation and samples from their liver were taken for histopathological preparations such as Hematoxylin-Eosin (H\&E) staining. Observation of the histopathological changes of rat hepatocytes included a picture of cell degenerations, such as fat vacuole in the cytoplasm (microvesicular or macrovesicular) and the presence or absence of necrosis signs (cell death), i.e., the hepatocyte nucleus appeared pycnotic, karyorrhexis, and karyolysis in five visual fields. To distinguish the severity of hepatocyte changes from one rat liver to another, the researchers classified them into five categories based on the average percentage of hepatocytes experiencing degeneration and necrosis. In the first category, liver cell damage did not occur in five fields of view. In the second, third, fourth, and fifth categories, $0-25 \%, 25-50 \%$, $50-75 \%$, and $75-100 \%$ of liver cells degenerated or experienced necrosis in five visual fields, respectively (Brunt et al., 1999). The magnification was set at $100 \times$ to determine which area would be observed, a magnification of $400 \times$ was used to more closely observe the characteristics of cells undergoing degeneration and necrosis. Observations were done using an Olympus CX 21 microscope, starting from the central venous area and other areas until five fields of view were obtained. Observational data based on the severity of liver cell damage were statistically analyzed.

\section{Statistical analysis}

The obtained results were then put under the difference test with the Kruskal Wallis statistical analysis test. If there was a significant difference $(\mathrm{p}<0.05)$, the Mann-Whitney test would be carried out to find out the differences between groups. All data were processed using the SPSS application, Statistical Program for Social Science 20 for windows.

\section{RESULTS}

\section{The fatty degeneration of white rats (Rattus norvegicus) hepatocytes}

Histopathological examination of the rat's liver treated with extract of purslane was followed by induction of a highfat diet. The results of mean ranks of fatty degeneration tested with the Kruskal Wallis test indicated significant 
differences $(p<0.05)$ and the results of the mean fatty degeneration using the Mann Whitney test did not indicate any significant difference between the treatment groups. The mean rank values of fatty degeneration of white rat hepatocytes are presented in Table 1.

As can be seen in Table 1, the mean value of fatty degeneration in each treatment group decreased although it was not significant. This was due to the different treatment which the $\mathrm{K}$ - treatment group was only given $1 \% \mathrm{CMC} \mathrm{Na} 1 \mathrm{~mL}$ on the 29th day, while the P3 treatment group was given Purslane extract therapy with a dose of $216 \mathrm{mg} / \mathrm{kg} \mathrm{BW}$, but still, differences were not significant. The P1 and P2 groups were, respectively, treated with Purslane extract at a dose of 54 $\mathrm{mg} / \mathrm{BW} \mathrm{kg}$ and $108 \mathrm{mg} / \mathrm{BW} \mathrm{kg}$, both groups also represented mean degeneration values that were not significantly different from the K-treatment group which was only given CMC Na $1 \%$ of $1 \mathrm{ml}$. Histopathological images of white rats' livers that experienced fatty degeneration can be seen in Figure 1.

Based on the degeneration image, it could be clearly seen that there was a cytoplasm of hepatocyte cells in the fat vacuole as pointed by arrows. The picture was taken with a $400 \times$ magnification with H\&E staining. The image results of the P1 treatment group did not indicate a significant difference from the P2 treatment. The $\mathrm{K}+$ treatment group indicated the most severe fatty degeneration, compared to the other treatments since the $\mathrm{K}+$ was not treated by using Purslane extract and was only given a high-fat diet for 56 days. The P3 treatment represented the least fatty degeneration of hepatocytes after a high-fat diet for 56 days with Purslane extract which was given for 28 days at a dose of $216 \mathrm{mg} / \mathrm{kg}$ BW, compared to the P1 and P2 treatment groups after high-fat diet given for 56 days and with Purslane extract at a dose of $54 \mathrm{mg} / \mathrm{kg} \mathrm{BW}$ and $108 \mathrm{mg} / \mathrm{kg} \mathrm{BW}$. This indicated that the administration of Purslane extract at a dose of the P3 treatment group was able to repair hepatocyte damage after a high-fat diet.

Table 1. Mean values of fatty degeneration in the liver cells of rats given Purslane extract on a high-fat diet

\begin{tabular}{lcc}
\hline Treatment & \multicolumn{2}{|c}{ Mean rank of fatty degeneration \pm SD } \\
\hline $\mathrm{K}+$ & $1.60^{\mathrm{c}} \pm 0.01$ & 0.432 \\
\hline $\mathrm{K}-$ & $0.55^{\mathrm{a}} \pm 0.01$ & 0.412 \\
\hline $\mathrm{P} 1$ & $1.45^{\mathrm{c}} \pm 0.01$ & 0.191 \\
\hline $\mathrm{P} 2$ & $0.85^{\mathrm{ab}} \pm 0.01$ & 0.251 \\
\hline $\mathrm{P} 3$ & $0.60^{\mathrm{ab}} \pm 0.01$ & 0.432 \\
\hline
\end{tabular}

* Different superscripts $(\mathrm{a}, \mathrm{b}$, and $\mathrm{c})$ in the same column show significant differences $(\mathrm{p}<0.05)$. $\mathrm{K}+$ : Positive control group, $\mathrm{K}-$ : Negative control group, P1, P2, and P3: Treatment groups with the Purslane extract therapy at the doses of 54, 108, and $216 \mathrm{mg} /$ day, respectively. SD: Standard Deviation.

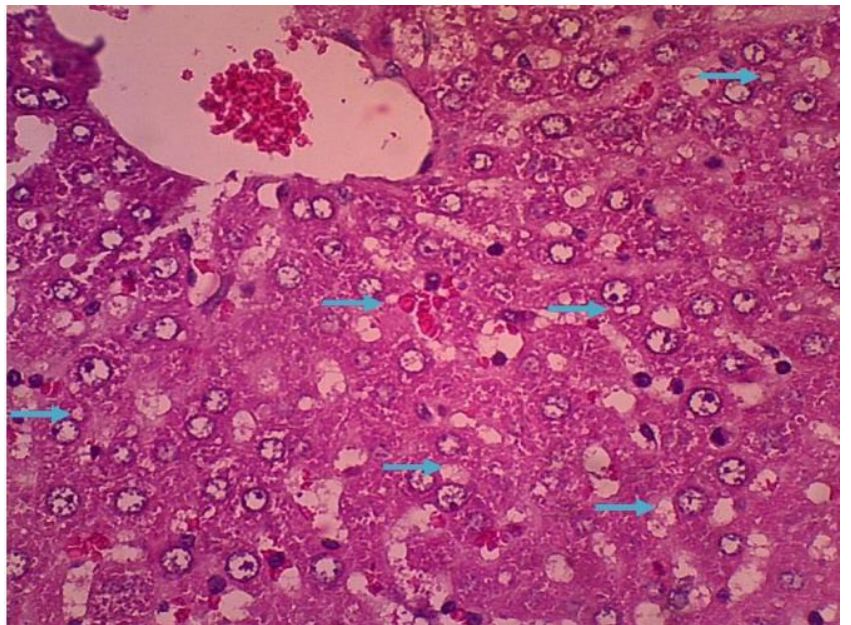

Figure 1. Image of fatty degeneration in rat hepatocytes in treatment group P2 as was given Purslane extract therapy with a dose of $108 \mathrm{mg} / \mathrm{kg} / \mathrm{BW}$

\section{White rat hepatocytes necrosis}

Microscopic observations of liver cell necrosis were analyzed by using the Kruskal Wallis test and indicated significant differences $(\mathrm{p}<0.05)$, the results from the analysis were tested using Mann Whitney test and presented significant differences $(\mathrm{p}<0.05)$ between treatment groups. The results of statistical analysis of hepatocyte necrosis observations can be seen in Table 2 .

According to Table 2, the K-treatment group that was only given $1 \mathrm{~mL}$ of CMC Na $1 \%$ was significantly different (p $<0.05$ ) from the treatment groups P1, P2, and P3 who were given Purslane extract with sequential doses of $54 \mathrm{mg} / \mathrm{Kg}$ $\mathrm{BW}, 108 \mathrm{mg} / \mathrm{Kg} \mathrm{BW}$ and $216 \mathrm{mg} / \mathrm{Kg} \mathrm{BW}$, respectively, which experienced decreased mean rank of necrosis. The decrease of necrosis means value in the P3 treatment group that was given Purslane extract at a dose of $216 \mathrm{mg} / \mathrm{kg}$ BW was the most significant, with the K-treatment group only given $1 \mathrm{~mL}$ of CMC Na $1 \%$. Histopathological images of the liver in white rats that experienced necrosis can be seen in Figure 2.

Histological image of white rat hepatocytes in the P3 group which was treated with Purslane extract at a dose of 216 $\mathrm{mg} / \mathrm{Kg} \mathrm{BW}$ resulted in the presence of a normal nucleus of hepatocyte cells as indicated by the yellow arrow and karyolysis appearing of the nucleus as indicated by the red arrow. The picture was taken with H\&E staining at 400x magnification. The $\mathrm{K}+$ treatment group presented the most severe necrosis compared to the $\mathrm{P} 3$ treatment group. This was due to the $\mathrm{K}+$ was not given a treatment with Purslane extract and was only given a high-fat diet for 56 days, whereas, P3 treatment was given Purslane extract at a dose of $216 \mathrm{mg} / \mathrm{kg} \mathrm{BW}$ which demonstrated smaller necrosis that was equal to $1.20 \pm 0.000$ approaching the mean value of necrosis in the negative treatment group that is equal to $1.00 \pm 0.000$. 
Table 2. Mean values of hepatocyte necrosis of rats given Purslane extract on a high-fat diet

\begin{tabular}{|c|c|c|}
\hline Treatment & \multicolumn{2}{|c|}{ Mean rank of necrosis \pm SD } \\
\hline $\mathrm{K}+$ & $1.85^{\mathrm{d}} \pm 0.01$ & 0.412 \\
\hline K- & $1.00^{\mathrm{a}} \pm 0.01$ & 0.000 \\
\hline P1 & $1.55^{\mathrm{cd}} \pm 0.01$ & 0.191 \\
\hline $\mathrm{P} 2$ & $1.25^{\mathrm{bc}} \pm 0.01$ & 0.191 \\
\hline P3 & $1.20^{\mathrm{b}} \pm 0.01$ & 0.000 \\
\hline \multicolumn{3}{|c|}{$\begin{array}{l}\text { Different superscripts }(\mathrm{a}, \mathrm{c}) \text { in the same column show significan } \\
\text { differences }(\mathrm{p}<0.05) . \mathrm{K}+\text { : Positive control group, K-: Negative } \\
\text { control group, P1, P2, and P3: Treatment groups with the Purslan } \\
\text { extract therapy at the doses of } 54,108 \text {, and } 216 \mathrm{mg} / \mathrm{day} \text {, respectively } \\
\text { SD: Standard Deviation. }\end{array}$} \\
\hline
\end{tabular}

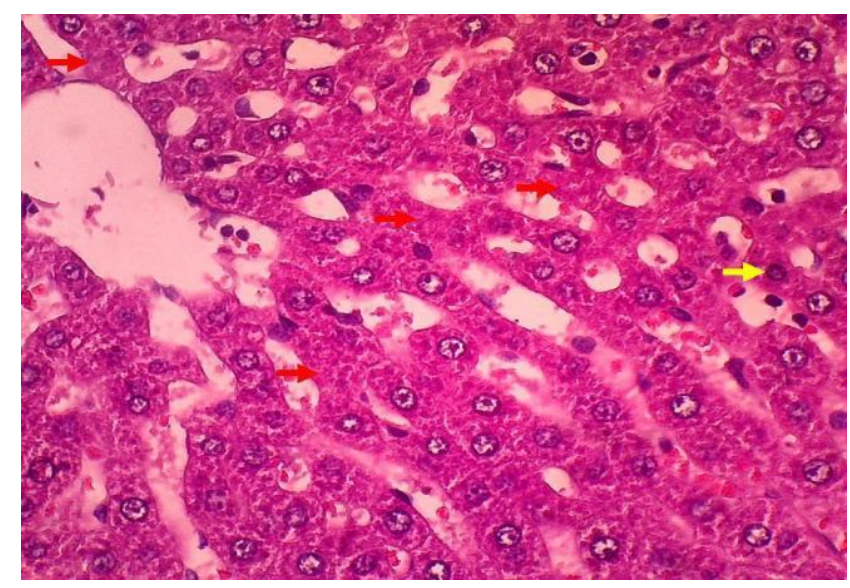

Figure 2. Description of necrosis in rat liver hepatocytes in treatment groups

\section{DISCUSSION}

High-fat diets can result in the formation of free radicals in the body (Lobo et al., 2010). In the current study, in the control group with no Purslane extract, the fatty degeneration was worse than the treatment group with Purslane extract. This condition can lead to various degenerative diseases, such as diabetes, cancer, diseases of the heart organ, and nervous system attacking diseases (Apostolova et al., 2011). The formation of free radicals causes serious damage to the health of the body including ischemia of the liver (Cichoż-Lach and Michalak, 2014).

In the present study, Purslane extract was able to repair damage to the liver of rats on a high diet. In P3 treatment, after giving a high-fat diet for 56 days and Purslane extract for 28 days at a dose of $216 \mathrm{mg} \mathrm{kg} / \mathrm{BW}$, the least amount of fatty degeneration in hepatocytes was observed. The tendency of Purslane extract in repairing hepatocytes damage is due to the presence of antioxidants and other compounds, including organic acids (oxalic acid, caffeine acid, malic acid, and citric acid), alkaloids, coumarin, flavonoids, cardiac glycosides, anthraquinone glycosides, alanine, catecholamines, saponins, and tannins (Boroushaki et al., 2004; Xin et al., 2008). In addition, Purslane also contains the highest concentration of omega-3 fatty acids, $\beta$-sitosterol (Rasheed et al., 2004), and beta carotene (Barbosa-Filho et al., 2008). Thus, the Purslane content can inhibit the occurrence of degenerative diseases and protect other compounds from oxidation

Several endogenous enzymes can ward off free radicals (Muriel, 2009). However, if the number of free radicals is excessive, due to a high-fat diet, the body needs exogenous antioxidants to ward off free radicals, therefore, antioxidants, such as Purslane extract, are needed as a medicinal ingredient to reduce the excess of free radicals in the body (PhamHuy et al., 2008). The last phase of ischemia is the occurrence of necrosis (Parola and Robino, 2001). The K+ treatment indicated a very severe image of necrosis, compared to other treatment groups. Liver necrosis is generally a continuation of a chronic history of liver disease (Parola and Robino, 2001). The decrease in necrosis is not yet significant because the number of active substances that act as antioxidants in purslane extract at these doses is still not effective enough to fight free radicals.

Liver damage necrosis can occur both focal or massive. Focal necrosis is local necrosis and affects only a few hepatocytes. However, massive necrosis or extensive necrosis affects the entire liver lobe. Cell death occurs as a result of plasma membrane damage and is preceded by several morphological changes such as cytoplasmic edema, dilatation of endoplasmic reticulum, triglyceride accumulation, mitochondria swelling, separation of organelles and their nuclei. The liver can regenerate, but extensive liver necrotic can lead to liver damage and even failure (Hodgson, 2004).

In the liver, free radicals due to the interference with cell membrane permeability and its function can cause oxidative stress which is characterized by damage to cell membranes and proteins, including enzymes (Mohssen, 2001; Babazadeh et al., 2021). Damage to cell membranes disrupts the ion channel process. The disturbed ion channel will cause ionic leakage and an increase in the amount of intracellular $\mathrm{Ca}^{2+}$. Increased intracellular $\mathrm{Ca}^{2+}$ can also be affected by damage to the function of $\mathrm{Ca}^{2+}$ ATPase and the $\mathrm{Na}^{+}-\mathrm{Ca} 2^{+}$exchanger system as a result of free radical attacks (Halliwell, 2007).

\section{CONCLUSION}

Purslane extract can reduce hepatocyte cell damage after giving high-fat diets. However, it has not been able to overcome the occurrence of necrosis yet. High-fat diets have not yet given the effect of triglyceride accumulation in hepatocytes in the form of fat vacuoles above normal limits. 


\section{DECLARATIONS}

\section{Competing interests}

The authors declared there was no conflict of interest.

\section{Ethical considerations}

Ethical issues (including plagiarism, consent to publish, misconduct, data fabrication and/or falsification, double publication and/or submission, and redundancy) have been checked by the authors.

\section{Authors' contribution}

All authors contributed equally to this work.

\section{REFERENCES}

Apostolova N, Blas-Garcia A, and Esplugues JV (2011). Mitochondria sentencing about cellular life and death: a matter of oxidative stress. Current Pharmaceutical Design, 17(36): 4047-4060. DOI: https://doi.org/10.2174/138161211798764924

Ariantari NP, Yowani SC and Swastini DA (2010). Uji aktivitas penurunan kolesterol produk madu herbal yang beredar di pasaran pada tikus putih diet lemak tinggi. Jurnal Kimia, 4(1): 15-19. Available at: https://ojs.unud.ac.id/index.php/jchem/article/view/2772/1964

Babazadeh D, Shabestari Ali, Sadeghi A, Saeed M, and Arman Moshavery (2021). Comparative histopathologic evaluation of the effects of Portulaca oleracea, Omega-3, and combination of sodium selenite and Vitamin E on hepatic enzymes of experimental diabetic rats. Small Animal Advances, 4-9. Available at: https://saa.rovedar.com/article_141322.html

Balk EM, Lichtenstein AH, Chung M, Kupelnick B, Chew P, and Lau J (2006). Effects of omega-3 fatty acids on serum markers of cardiovascular disease risk: a systematic review. Atherosclerosis, 189 (1): 19-30. DOI: https://doi.org/10.1016/j.atherosclerosis.2006.02.012

Barbosa-Filho JM, Alencar AA, Nunes XP, Tomaz AC, Sena-Filho JG, Athayde-Filho PF, Silva MS, Souza MV, and Da-Cunha EV (2008). Sources of alpha-beta-gamma-delta-and epsilon-carotenes: A twentieth century review. Revista Brasileira de Farmacognosia, 18(1): 135-154. DOI: https://doi.org/10.1590/S0102-695X2008000100023

Besong SA, Ezekwe MO, and Ezekwe EI (2011). Evaluating the effects of freeze-dried supplements of purslane (Portulaca oleracea) on blood lipids in hypercholesterolemic adults. International Journal of Nutrition and Metabolism, 3(4): 43-49. DOI: https://doi.org/10.5897/IJNAM.9000013.

Boroushaki MT, Boskabady MH, and Malek F (2004). Antitussive effect of Portulaca oleracea L. in guinea pigs. Iranian Journal of Pharmaceutical Research, 3: 187-190. DOI: https://dx.doi.org/10.22037/ijpr.2010.599

Brunt EM, Janney CG, Di Bisceglie AM, Neuschwander-Tetri BA, and Bacon BR (1999). Nonalcoholic steatohepatitis: a proposal for grading and staging the histological lesions. The American Journal of Gastroenterology, 94(9): 2467-2474. DOI: https://doi.org/10.1111/j.1572-0241.1999.01377.x

Calleja L, París MA, Paul A, Vilella E, Joven J, Jiménez A, Beltrán G, Uceda M, Maeda N, and Osada J (1999). Low-cholesterol and high-fat diets reduce atherosclerotic lesion development in ApoE-knockout mice. Arteriosclerosis, Thrombosis, and Vascular Biology, 19 (10): 2368-2375. DOI: https://doi.org/10.1161/01.ATV.19.10.2368

Chao PM, Chao CY, Lin FJ, and Huang CJ (2001). Oxidized frying oil up-regulates hepatic Acyl-CoA oxidase and cytochrome P450 4 Al genes in rats and activates PPAR $\alpha$. The Journal of Nutrition, 131(12): 3166-3174. DOI: https://doi.org/10.1093/jn/131.12.3166.

Cheng X, Hong X, Khayatnezhad M and F. Ullah (2021). Genetic diversity and comparative study of genomic DNA extraction protocols in Tamarix L. species. Caryologia, 74(2): 131-139. DOI: https://doi.org/10.36253/caryologia-1056

Cichoż-Lach H and Michalak A (2014). Oxidative stress as a crucial factor in liver diseases. World Journal of Gastroenterology, 20(25): 8082-8091. DOI: https://doi.org/10.3748/wjg.v20.i25.8082

Den Boer M, Voshol PJ, Kuipers F, Havekes LM, and Romijn JA (2004). Hepatic steatosis: a mediator of the metabolic syndrome. Lessons from animal models. Arteriosclerosis, Thrombosis, and Vascular Biology, 24 (4): 644-649. DOI: https://doi.org/10.1161/01.ATV.0000116217.57583.6e

Ghadir MR, Riahin AA, Havaspour A, Nooranipour M, and Habibinejad AA (2010). The relationship between lipid profile and severity of liver damage in cirrhotic patients. Hepatitis Monthly, 10(4): 285-288. Available at: https://pubmed.ncbi.nlm.nih.gov/22312394/

Halliwell B (2007). Biochemistry of oxidative stress. 35(5): 1147-1150. DOI: https://doi.org/10.1042/BST0351147

Hodgson E (2004). A textbook of modern toxicology. John Wiley \& Sons, Inc.

Koch A, König B, Spielmann J, Leitner A, Stangl GI, and Eder K (2007). Thermally oxidized oil increases the expression of insulininduced genes and inhibits activation of sterol regulatory element-binding protein-2 in rat liver. The Journal of Nutrition, 137 (9): 2018-2023. DOI: https://doi.org/10.1093/jn/137.9.2018

Kusriningrum RS (2012). Experiment Design, Surabaya: Airlangga University, pp. 43-63.

Lichtenstein AH, Appel LJ, Brands M, Carnethon M, Daniels S, Franch HA, Franklin B, Kris-Etherton P, Harris WS, Howard B, Karanja N, Lefevre M, Rudel L, Sacks F, Horn LV, Winston M, and Wylie-Rosett J (2006). Diet and lifestyle recommendations revision 2006: a scientific statement from the American Heart Association Nutrition Committee, 114(1): 82-96. DOI: https://doi.org/10.1161/circulationaha.106.176158 
Lobo V, Patil A, Phatak A and Chandra N (2010). Free radicals, antioxidants and functional foods: Impact on human health. Pharmacognosy Reviews, 4(8): 118-126. DOI: https://doi.org/10.4103/0973-7847.70902

Mohssen M (2001). Biochemical and histopathological changes in serum creatinine and kidney induced by inhalation of Thimet (Phorate) in male Swiss albino mouse, Mus musculus. Environmental Research, 87(1): 31-36. DOI: https://doi.org/10.1006/enrs.2001.4285

Muriel P (2009). Role of free radicals in liver diseases. Hepatology International, 3: 526-536. DOI: https://doi.org/10.1007/s12072$\underline{009-9158-6}$

Murray RK, Granner DK, Mayes PA, and Rodwell VW (2003). Harper's illustrated biochemistry. New York Chicago San Francisco Lisbon London Madrid Mexico City, $254 . \quad$ Available at: http://www.eqas.ir/pdf/lib/Harper\%20Illustrated\%20Biochemistry\%202003.pdf

Parola M and Robino G (2001). Oxidative stress-related molecules and liver fibrosis. Journal of Hepatology, 35(2): 297-306. DOI: https://doi.org/10.1016/S0168-8278(01)00142-8

Pham-Huy LA, He H, and Pham-Huy C (2008). Free radicals, antioxidants in disease and health. International Journal of Biomedical Science, 4(2): 89-96. Available at: https://www.ncbi.nlm.nih.gov/pmc/articles/PMC3614697/

Rasheed AN, Afifi FU, Shaedah M, and Taha MO (2004). Investigation of the active constituents of Portulaca oleraceae L. (Portulacaceae) growing in Jordan. Pakistan Journal of Pharmaceutical Sciences, 17(1): 37-45. Available at: https://www.researchgate.net/publication/7356940

Xin HL, Xu YF, Yue XQ, Hou YH, Li M, and Ling CQ (2008). Analysis of chemical constituents in extract from Portulaca oleracea L. with GCMS method. Pharmaceutical Journal of Chinese People's Liberation Army, 24: 133-136. Available at: https://en.cnki.com.cn/Article_en/CJFDTotal-JFJN200802013.htm 